DOI 10.22394/1818-4049-2017-79-2-182-185

УДК 351.777

\title{
А.В. Ярославцев
}

\section{Экологические инновации в ЖКХ: особый вклад в улучшение качества жизни горожан}

Современный город невозможно представить с переполненными урнами, окруженньм полигонами и нелегальньми свалками. Для формирования нового качества российских городов и общественного пространства регионам было поручено провести ряд мероприятий по запуску новой системы обращения с отходами - от выстраивания системы сбора коммунальных отходов до строительства современных мусороперерабатывающих заводов. В 2016 и 2017 г2. столииа Сибири (2. Новосибирск) стала площадкой для проведения Международного форума "Городские технологии, где обсуждались новые технологии для повседневной жизни граждан. Инноваиионные технологии, представленные на форуме, имеют положительный практический опыт применения. Как отмечал А.Н. Аюлько: "... инновации не внедряются ради инноваций. C их помощъю решаются важнейшие задачи" [5].

В настоящей статье показаны инновационные разработки в жилищнокоммунальном хозяйстве, имеющие практическое применение в Сибирском федеральном округе.

The modern city can't be presented with the overflowed ballot box for garbage, surrounded with the grounds and illegal dumps. For formation of a new quality of the Russian cities and public spaces it was entrusted to the regions to hold a number of events for starting of a new system of collecting the waste - from forming of a system of collecting municipal waste, before construction of the modern waste recycling plants. In 2016 and 2017 the capital of Siberia (Novosibirsk) became the platform for holding the International forum "City Technologies" where the new technologies for everyday life of citizens were discussed. The innovative technologies presented at that forum have positive practical experience of application. As A.N. Lyul'ko noted rinnovations don't take root for the sake of innovations. The major problems are solved with their helpw.

Innovative developments in the housing and communal services having practical application in the Siberian federal district are shown in this article.

Ключевые слова: экологическое состояние городов, качество жизни горожан, инноваиии, технологии, коммунальные отходы, Международный форум "Городские технологии".

Keywords: ecological condition of the cities, quality of life of the citizens, innovations, technologies, municipal waste, International forum "City Technologies".

До января 2017 г. российские компании домжны были подать в Федерамьную службу по надзору в сфере природопользования заявки о постановке на учет объектов негативного воздействия на окружающую среду (дамее - НВОС). Государственная регистрация объектов НВОС затрагивает практически весь реальный сектор экономики. В России на- считывалось около 300 тыс. предприятий, подмежащих федеральному надзору в данной сфере [4]. В соответствии со ст. 8.46 КоАП установмена административная ответственность за невыполнение обязанности по подаче заявки на постановку на учет объектов НВОС (дАя юридических миц от 30 до 100 тыс. руб.). Так, в начаме декабря 2016 г. в эмектронном

Ярославцев Александр Вцадимирович - канд. ист. наук, доцент кафедры менеджмента и предпринимательского права, Дальневосточный институт управления филиал РАНХиГС (г. Хабаровск). E-mail: mu322@mail.ru 
виде бымо подано окомо 50 тыс. заявок на постановку на учет. С 1 января 2019 г. в КоАП вступит в сииу ст. 8.47 , в которой предусмотрено получение "компиексного экологического разрешения" на осуществмение хозяйственной и иной деятельности на объектах НBOC [3].

С 1 января 2017 г. в России поэтапно запускается новая система обращения с отходами. Выстраивание эффективной системы обращения с отходами, в том чисме своевременной уборки общественных пространств и вывоза отходов - важнейший эмемент реамизации приоритетного проекта "ЖKX и городская среда" [6].

Новая система позвомит упорядочить и автоматизировать государственный учет объектов НВОС, сдемать его понятным, прозрачным и беспристрастным. Созданная информационная система позволит получать более точную информацию об экомогической напряженности по конкретным территориям. Например, выявценное количество объектов, которые производят выбросы в атмосферный воздух в том или ином городе, позволят органам государственного управмения квотировать общий объем этих выбросов. Предприятиям это также будет выгодно. Например, если предприятие будет вести деятельность только на объектах IV класса опасности, то оно освободится от экомогических платежей и проверок Росприроднадзора. Если организация обоснует, что ее объекты не оказывают негативного воздействия, не загрязняют почву, воду ики воздух, то она выходит из-под экоцогического надзора, что снижает административные барьеры. Если объект относится к разряду повышенной экологической опасности (I категория), но на нем используются современные техномогии (наилучшие доступные техномогии), то предприниматемь может получить существенные преференции. Данные преобразования особенно актуальны дия ЖKX.

В рамках Международного форума "Городские техномогии" были представмены инновационные техномогии в обцасти переработки и утимизации отходов $[1,2]$.
Компиексное управмение отходами предприятий г. Новосибирска осуществАяет компания "Чистый Город". Одним из этапов является комплесного управления вторичная переработка (рециклинг) и обезвреживание отходов. Компания "Экособер" разработала новую техномогию "Вэйствуд". Это безотходная, экомогически безопасная, экономически эффективная технология переработки отходов твердых бытовых (вкАючая помигонные) и некоторых промышленных (отходов животноводства, сельскохозяйственного производства, текстицьной, пищевой промышиенности). В резумьтате переработки компания производит уникальную продукцию с практически абсомютной невосприимчивостью к действию вцаги, агрессивных сред, микроорганизмов, высоких и низких температур, умьтрафиолетового измучения, пользуюшуюся повышенным спросом в размичных областях применения.

В сфере экологически чистой переработки отходов с получением дополнительньг продуктов - тепловой и электроэнергии, высококачественных органических удобрений, биогаза - успешно реализуются инновации на практике "ГК СибБиоГаз». На основе возобновцяемьг источников энергии проектируются и строятся объекты энергетики: биогазовые станции, сомнечные эмектростанции, системы горячего водоснабжения и отопления на основе сомнечныг комекторов.

Проект, направценный на умучшение экологии, экономию строитемьства новых мусорньгх помигонов, сокращение объема сжигаемого мусора, реализуется мусороперерабатывающей компанией "Полимер Рецикл-Н" совместно с компанией "Тайгер-Сибирь" в г. Новосибирске. В рамках проекта компании установими на мусорных пиощадках города сетчатые конструкции дия сбора стекиа, пластика и алюминия.

Компании "Центр Утилизации», одно из крупнейших специамизированных предприятий Сибирского федерахьного округа, и "Утимитсервис" используют инсинераторы ${ }^{1}$ размичных модемей, по-

\footnotetext{
${ }^{1}$ Примечание: инсинераторы - специализированные установки для контролируемого высокотемпературного экологически безопасного термического уничтожения (сжигания) и обезвреживания практически всех видов отходов.
} 
зволяющие обеспечить высокотемпературное (до 1200 С) уничтожение отходов со $100 \%$ обезвреживанием, способствуют тем самым уменьшению их объема на $90-95 \%$ и искАючают риск загрязнения окружающей среды бомезнетворными микроорганизмами.

Группой компаний "Тион" разработаны "земенные" техномогии тепмоснабжения, которые позволяют утилизировать сбросовое тепло от производств в систему централизованного теплоснабжения, что дает снижение эмиссии $\mathrm{CO}^{2}$ за счет вытеснения сжигания угля в котельньх.

Инновационные разработки в обцасти водоочистки представмены учеными Новосибирского государственного архитектурно-строительного университета, Института цитологии и генетики Сибирского отдемения Российской академии наук и другими разработчиками.

На основе комплексных исследований, производственных испытаний оборудования и процессов в Новосибирском государственном архитектурностроительном университете разработаны универсальная, экомогически безопасная технология подготовки питьевой воды из поверхностньх и подземньх источников дмя питьевого водоснабжения насеменньг пунктов, а также новое высокоэффективное водоочистительное оборудование, способы утилизации промывных сточных вод и осадка, способы получения активного фимьтрующего материала. Предлагаемые методы и сооружения защищены 12 патентами на изобретения.

Ученые из Института цитологии и генетики Сибирского отдемения Российской академии наук разработали техноАогию очистки сточных вод с помощью биопрудов, засеменных эйхорнией отАичной (водяным гиацинтом). Это растение хорошо погмощает радионукмиды тяжемых метамлов. "Фабрика" дия его кумьтивирования создана в институте Сибирского отдемения Российской академии наук.

Компания Сибирских водных технологий "Гибридная технология" - это команда ученых и инженеров, работающих над созданием систем водоочистки, способных гармонично вписаться в существующую экосистему. Профимем компании явцяется автономная очистка и утилизация хозбытовых сточных вод на месте водопотребления. Новая техномогия закАючается в раздемьной обработке стоков разАичного происхождения, что позволяет сочетать биологические и физико-химические процессы обработки отдельных компонентов стока, удешевцяя систему. Совместно с партнером - компанией "Вакуумные системы автоматики" - поставмяет установки УФ-облучения с паралмельным озонированием воды дмя получения ультрафиомета и озона в мальгх количествах, дАя обработки воды.

Инновационные технологии в сфере энергосбережения и перевода транспорта на экологически чистый источник

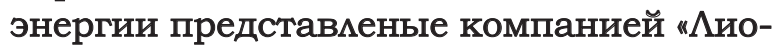
тех инновации", разработаны на основе высокоемких митий-ионных аккумуляторов нового покомения дия безопасного хранения и использования энергии.

Российским производителем инновационных технологий для ЖKX и строительства Научно-производственным предприятием "Р-техно" представмены научные разработки по созданию малогабаритного энергоёмкого и экологически безопасного оборудования.

В области благоустройства инновационные разработки, позволяюшие положительно повлиять на экологию городской среды, представмены учеными ряда вузов. В частности, Институтом горного дема им. Н.А. Чинакала СО РАН разработаны пневмоударные машины дяя бестраншейной прокладки коммуникаций в грунте (пневмопробойники), назначение которых - образование в уплотняемых грунтах скважин дииной до 40 м с целью последующей прокладки в них коммуникаций размичного назначения. Пневмопробойники успешно применяются при проходке скважин под улицами, трамвайными и железнодорожными путями, автострадами, взцетно-посадочными поАосами аэродромов, при реконструкции подземных коммуникаций и т.д.

Сотрудниками Новосибирского государственного технического университета разработана мобильная установка дия очистки мьда с тротуаров. Разработан культиватор, в котором вместо ножей используются щетки из метамиа. Уникальность технологии в том, что в про- 
цессе очистки мьда куцьтиватор не наносит повреждений тротуарному слою, чего практически невозможно добиться при механической ими ручной очистке медяной корки.

Ученые научного подраздемения крупнейшего ботанического учреждения

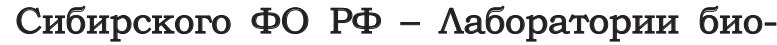
техномогии «Центрамьный сибирский ботанический сад СО $\mathrm{PAH}$ - разработали технологию производства декоративньх кумьтур методами биотехномогии, которая позволяет повысить качество оземенительных работ, а также расширить ассортимент плодово-ягодных растений дия потребитемей.

Разработка, направленная на восстановмение плодородия почв, представмена Институтом химии твердого тела и механохимии СО $\mathrm{PAH}$. Ее результатом явцяется новый гуматный продукт, предназначенный дмя реанимирования грунта, подверженного высокой техногенной нагрузке.

Таким образом, новые технологии и научные разработки в сфере жимищнокоммунального хозяйства способствуют модернизации и эффективности муниципахьного хозяйства, что уиучшит экомогическое состояние городов и качество жизни горожан.

\section{Cписок литературы:}

1. Материалы Международного форума «Городские технологии. - Изд-во Департамента промышиенности, инноваций и предпринимательства мэрии г. Новосибирска. - Новосибирск, 2016. - 129 c.

2. Материалы Международного форума «Городские технологиш. - Изд-во Департамента промышленности, инноваиий и предпринимательства мэрии г. Новосибирска. - Новосибирск, 2017. - $150 \mathrm{c}$.

3. О внесении изменений в Федеральный закон "Об охране окружаюшей средь" и отдельные законодательные акты Российской Федераиии : федер. закон от 21.07.2014 2. № 219-Ф3 // Собр. законодательства РФ. - 2014. - № 30. - Сm. 4220.
4. Официальный сайт Федеральной службы nо надзору в сфере природопользования. URL.: http://rpn.gov.ru.

5. Примечание: А.Н. Аюлько - начальник департамента промышленности, инноваций $u$ предпринииательства мэрии г. Новосибирска // Материалы Международного форума «ородские технологии. - Изд-во Департамента промышленности, инноваиий и предпринимательства мэрии г. Новосибирска. - Новосибирск, 2017.

6. Стратегическое направление развития "ЖKX $u$ городская среда" [Электронный ресурс] // Официальный сайт Министерства строительства и жилицно-коммунального хозяйcmва Pоссийской Федераuиu. URL.: http://www. minstroyrf.ru.

\section{References:}

1. Materialy Mezhdunarodnogo foruma "Gorodskie tekhnologii". - Izd-vo Departamenta promyshlennosti, innovacij $i$ predprinimatel'stva mehrii g. Novosibirska. - Novosibirsk, 2016. $129 \mathrm{~s}$.

2. Materialy Mezhdunarodnogo foruma "Gorodskie tekhnologii". - Izd-vo Departamenta promyshlennosti, innovacij i predprinimatel'stva mehrii g. Novosibirska. - Novosibirsk, 2017. $150 \mathrm{~s}$.

3. O vnesenii izmenenij v Federal'nyj zakon "Ob ohrane okruzhayushchej sredy" $i$ otdel'nye zakonodatel'nye akty Rossijskoj Federacii : feder. zakon ot 21.07.2014 g. № 219-FZ // Sobr. zakonodatel'stva RF. - 2014. - № 30. - St. 4220.

4. Oficial'nyj sajt Federal'noj sluzhby po nadzoru $v$ sfere prirodopol'zovaniya. URL.: http:// rpn.gov.ru.

5. Primechanie: A.N. Lyul'ko - nachal'nik departamenta promyshlennosti, innovacij $i$ predprinimatel'stva mehrii g. Novosibirska // Materialy Mezhdunarodnogo foruma "Gorodskie tekhnologii". - Izd-vo Departamenta promyshlennosti, innovacij $i$ predprinimatel'stva mehrii g. Novosibirska. - Novosibirsk, 2017.

6. Strategicheskoe napravlenie razvitiya "ZHKH i gorodskaya sreda" [EHlektronnyj resurs] // Oficial'nyj sajt Ministerstva stroitel'stva $i$ zhilishchno-kommunal'nogo hozyajstva Rossijskoj Federacii. URL.: http://www.minstroyrf.ru. 